\title{
Seasonal influences on ungulate movement within a fenced South African reserve
}

\begin{tabular}{|r|l|}
\hline Journal: & Journal Of Tropical Ecology \\
\hline Manuscript ID & JTE-18-063.R2 \\
\hline Manuscript Type: & Short Communication \\
\hline Date Submitted by the Author: & n/a \\
\hline Complete List of Authors: & $\begin{array}{l}\text { O'Kane, Christopher; University of Oxford, Wildlife Conservation Research } \\
\text { Unit; University of Oxford, Worcester College } \\
\text { Macdonald, David; University of Oxford, Wildlife Conservation Research } \\
\text { Unit }\end{array}$ \\
\hline Keywords: & $\begin{array}{l}\text { body-size, burns, grazers, Hartebeest, impala, SAVANNA, warthog, zebra, } \\
\text { Wildebeest }\end{array}$ \\
\hline &
\end{tabular}

\section{SCHOLARONE ${ }^{\text {m }}$}

Manuscripts 


\section{Seasonal influences on ungulate movement within a fenced South African reserve}

Running title: Ungulate seasonal movements

Key words: body-size, burns, grazers, hartebeest, impala, savanna, warthog, wildebeest, zebra

Word count: 2,000

Christopher A.J. O'Kane ${ }^{\text {a, } 1}$

David W. Macdonald ${ }^{\text {a }}$

${ }^{a}$ Wildlife Conservation Research Unit, Department of Zoology, University of Oxford, The Recanati-Kaplan Centre, Tubney House, Abingdon Road, Tubney, Oxon OX13 5QL, United Kingdom.

${ }^{1}$ Corresponding author: christopher.okane@zoo.ox.ac.uk 


\begin{abstract}
The movement of African ungulates between habitats is determined by diverse factors including forage composition, availability and quality, water availability, topography, the catenary level and the effect of fire on vegetation. We assessed how grass flushes, following dry-season fires, and availability of water influenced seasonal movements of hartebeest, impala, warthog, white rhino, wildebeest and zebra in Ithala Game Reserve, a fenced reserve in South Africa. Over a 6-d period each month for 4 y, road transects covering a representative sample of the reserve's different vegetation types, and $23 \%$ of the reserve's total area, were carried out. We recorded the species, number, sex and age class of herbivores, obtaining 8742 records (total herbivores sighted $=47,055)$, and obtained positional data on sightings over the last $2 \mathrm{y}$ of the study. Using a GIS-based approach, we determined that ruminant, but not non-ruminants, were significantly attracted to dry-season grass flushes, and that presence or absence of such flushes significantly affected their mean distance to water and hence seasonal movements on the catena.
\end{abstract}


Large herbivores prefer certain habitat types and, consequently, are not uniformly distributed while foraging (Ferrar \& Walker 1974, Hirst 1975). For African ungulates, day-to-day movement between habitats is determined by diverse factors including forage composition, availability and quality, water availability, topography, soil type (BenShahar \& Coe 1992) and predation (Grand 2002). Additional seasonal movements relate to climatic conditions, the catenary level (Bell 1969) and the effect of fire on vegetation (Crowe et al. 1981). We assessed how grass flushes, following dry-season fires, and availability of water influenced different ungulates' seasonal movements in Ithala Game Reserve - a fenced South African reserve characterised by abrupt topography.

Although often started and controlled by management, fire is a natural and integral part of savanna ecosystems (Scholes \& Walker 1982). A few days after burning the residual tufts of grass drive out new growth, triggered by the fire induced 'heat shock', provided enough soil moisture is available (Sturm 1993). As plants age, their concentration of protein decreases whilst the proportion of relatively indigestible crude fibre increases - the young grass is thus high in protein and easily digestible, giving it high nutritive value (McDonald et al. 1966) especially as elsewhere in the dry season food availability is low and grass quality poor (Huntley \& Walker 1982). This attractiveness of newly burnt areas to large herbivores is widely recognized (Moe et al. 1990, Wilmshurst et al. 1999), and the comparative usage of such areas by different herbivore species has been investigated (Tomor \& Owen-Smith 2002). Wilsey (1996) proposed that relative use of green flushes following burns among African ungulates was related to body size; larger animals utilising them less due to their ability to survive on relatively lower quality foods (Illius \& Gordon 1992), consequent on the inter- 
relationships between body size, energy (Hungate et al. 1959) and protein turnover (Brody et al. 1934) and gut capacity (Illius \& Gordon 1992).

The relationship between herbivores' distance to surface-water and the season will vary according to the interplay between water availability and topography. Animals will remain within reach of water, according to their varying temporal requirements, and therefore if water sources are restricted animals will occur in higher concentrations in their vicinity than elsewhere. In such cases declining quality and quantity of forage over the dry season will force herbivores to forage further away from the water, leading to an increase in mean distance of herbivores from surface water (Redfern et al. 2003). This will especially be the case in flatter regions where catena effects (Bell 1969), which lead to better resources down the catena (i.e. closer to water), are minimal. At the other extreme, if water is freely available and places no restriction on animal range, animals will be distributed irrespective of surface water. Topography will again modify how dryseason forage shortage influences herbivores' distance from water, but now flat areas would be expected to show little change whilst in hilly areas herbivores would be expected to move down the catena and hence closer to water. Consequently in areas where water is freely available with markedly varied topography, as in Ithala, mean distances to surface water would be expected to decrease in the dry season.

We hypothesised that (1) larger ungulates would be less attracted to grass flushes than smaller ungulates, and (2) ungulates' mean distance to water would decrease in the dry season.

Ithala Game Reserve (29,653 ha) is situated in northern KwaZulu Natal, South Africa $\left(27^{\circ} 30^{\prime} \mathrm{S}, 31^{\circ} 25^{\prime} \mathrm{E}\right)$. Full details of the study site are given in O'Kane et al. 
(2014b). Over the 4-y study mean annual rainfall (632 mm) was below average, with annual rainfall in Year 2 noticeably lower $(427 \mathrm{~mm})$. The reserve carries moderate densities of impala Aepyceros melampus Lichtenstein $\left(10 \mathrm{~km}^{-2}\right)$, a mixed-feeder, but high densities of wildebeest Connochaetes taurinus taurinus Burchell $\left(6 \mathrm{~km}^{-2}\right)$ and zebra Equus burchelli Gray $\left(5.6 \mathrm{~km}^{-2}\right)$ (O'Kane et al. 2014a, b).

Over a 6-d period each month, for $4 \mathrm{y}$, road transects covering a representative sample of the reserve's different vegetation types, and $23 \%$ of the reserve's total area, were carried out. Transects were driven at the same time during the morning and afternoon on each field trip, with midday avoided. Once within a classifiable distance with an unobstructed view of the individual/group of herbivores, the total number of animals, the species, their age and sex were determined as per Brooks (1985). Spatial data were collected over the last $2 \mathrm{y}$ of the study and the coordinates of each sighting were imported into a GIS (ArcGIS 9 by ESRI). During the collection of spatial data, the presence or absence of a grass flush at each sighting was recorded. Grass flushes only occurred, following fire and then rainfall, over the dry season of the first year in which spatial data were gathered (Year 3). Taking the field trip where major flushes were observed and using the query builder in ArcGIS 9, all records where the sighting was situated on a flush were selected and converted to a separate shape file and added to the view. Polygons were then drawn, by eye, around each large concentration of herbivores on a flush, and flushes were grouped into those occurring on high, mid-, or low-elevation grasslands. By calculating the area of the polygons, densities of each herbivore species on the flush were determined. These same polygons were then used to determine densities on the same parcels of land 1 mo (i.e. one field trip) before the appearance of the major 
flush. The null hypothesis was that there was no difference between these densities and this was tested, for each herbivore species and each flush grouping, using Pearson's Chisquared test with Yates' continuity correction with P-values $\leq 0.05$ taken as significant.

Ungulate species were analysed separately, with the null hypothesis being that there was no difference in the mean distance to water during the dry season compared to the wet season. Fisher's F-test was used to determine whether variances in means were significantly different, with the standard two-sample t-test (equal variances) or Welch's modified two-sample t-test (unequal variances) then used to test the null hypothesis. Pvalues $\leq 0.05$ resulted in rejection of the null hypothesis, i.e. represented significant differences between mean distances to water in the dry versus wet season. Statistical procedures were carried out in S-PLUS (Mathsoft, Lucent Technologies, Inc., Murray Hill, USA).

Impala and warthog Phacochoerus aethiopicus Pallas were significantly attracted to grass flushes at any elevation, wildebeest to those at mid- and lower elevations, whilst hartebeest Alcelaphus buselaphus Pallas only to those at mid-elevations (Figure 1).

Although a few zebra were observed on grass flushes, there was no significant increase in their densities compared to prior to the flush. White rhino Ceratotherium simum Burchell was not observed on grass flushes.

During the dry season of Year 3, the mean distance from water of impala, warthog and wildebeest was significantly greater than in the preceding wet season, whilst white rhino and zebra were significantly closer (Table 1). During the dry season of Year 4, the mean distances from water of all studied ungulates was significantly less than the preceding wet season, except for white rhino where this finding was not significant. 
That impala, warthog and wildebeest made most use of flushes agrees with the findings of others (Crowe et al. 1981, Field \& Laws 1970, Gureja \& Owen-Smith 2002, Shackleton 1992, Tomor \& Owen-Smith 2002, Wilmshurst et al. 1999, Wilsey 1996, Wronski 2003), as does our finding that zebra made little use of them (Wilsey 1996). As one of the larger grazers, wildebeest, was heavily attracted to grass flushes whilst the similar-sized zebra was not, our findings did not support our (first) hypothesis that larger ungulates would be less attracted to flushes than smaller ungulates. Wilsey (1996), although he first proposed this hypothesis, found only a weak $\left(\mathrm{r}^{2}=0.29 ; \mathrm{P}>0.05\right)$ linear regression between body size and use of grass flushes in the Serengeti, with wildebeest showing marked use of flushes. Tomor \& Owen-Smith (2002) did not find any significant relationship between body size and use of flush. This differential pattern of usage suggests that the missing part in Wilsey's proposal is the influence of gut morphology; namely ruminant versus non-ruminant. Ruminants, such as impala, warthog and wildebeest, being more dependent on quality of forage than quantity (Owen-Smith \& Novellie 1982), are likely to be more attracted during times of resource scarcity to flushes than non-ruminants, such as zebra, which can cope with such conditions by increasing their intake of lower-quality forage. Non-ruminants would be expected to still desire the quality new grass in the depths of the dry season, but ruminants need would be greater as they have no easy alternative - thus zebra may be being competitively displaced from the flushes. Even where zebra have been seen on flushes to a more marked extent, they were observed to be the least restricted in their occupation of the different vegetation zones apparent in the flush area (Tomor \& Owen-Smith 2002) - again likely to be due to their non-ruminant digestion. 
It was noticeable in our results that despite occupying high-elevation grasslands before the appearance of grass flushes, wildebeest left these areas apparently when flushes appeared. This was probably because burning occurred over the period when wildebeest, over all four years of the study, were seen to abandon the higher elevations and move down the catena. Even so it is interesting that for a species renowned at detecting and travelling large distances for fresh grass growth (Talbot \& Talbot 1963), wildebeest did not travel back up the catena to utilise this resource. The study highlighted the importance of the timing of management burns in relation to dry-season rainfall over the dry season of Year 3 burning occurred just prior to substantial dry-season rains, producing a marked flush, but in Year 4 dry-season burning occurred well after the rains resulting in a very sparse flush.

Over the dry season when grass flushes did not occur (Year 4) ungulates' mean distance to water decreased, thus supporting our (second) hypothesis. However when dryseason grass flushes did occur (Year 3) ruminant grazers increased their mean distance to water, as they moved higher up the catena to where most burning, and hence flushes, occurred. Non-ruminant grazers (white rhino and zebra) were not attracted to these flushes and thus, as expected, moved down the catena closer to water.

\section{ACKNOWLEDGEMENTS}

We thank the reserve management of Ithala Game Reserve, South Africa, for access to the reserve, and Bruce Page for help with data collection. Dr. O'Kane holds the Kadas Research Fellowship at WildCRU, Department of Zoology, University of Oxford and is deeply grateful to Gyongyver and Peter Kadas for their support. 


\section{LITERATURE CITED}

BELL, R. 1969. The use of the herb layer by grazing ungulates in the Serengeti. Pp. 111124 in Watson, A. (ed). Animal populations in relation to their food resources.

Symposium of the British Ecological Society. Blackwell, Oxford.

BEN-SHAHAR, R. \& COE, M. J. 1992. The relationship between soil factors, grass nutrients and the foraging behavour of wildebeest and zebra. Oecologia 90:422-428. BRODY, S., PROCTOR, R. C. \& ASHWORTH, U. S. 1934. Growth and development with special reference to domestic animals, Part 34. Research Bulletin University of Missouri Agricultural Research Experiment Station 220:32.

BROOKS, P. M. 1985. Classification of large herbivores in Ithala Game Reserve. Natal Parks Board, Pietermaritzburg. 18 pp.

CROWE, T. M., SCHIJF, J. C. \& GUBB, A. A. 1981. Effects of rainfall variation, fire, vegetation and habitat physiogmomy on a northern Cape animal community. South African Journal of Wildlife Research 11:87-104.

FERRAR, A. A. \& WALKER, B. H. 1974. An analysis of herbivore-habitat relationships in Kyle National park, Rhodesia. Journal of the South African Wildlife Management Association 4:137-147.

FIELD, C. R. \& LAWS, R. M. 1970. The distribution of the larger herbivores in the Queen Elizabeth National Park,Uganda. Journal of Applied Ecology 7:273-294.

GRAND, T. C. 2002. Alternative forms of competition and predation dramatically affect habitat selection under foraging-predation-risk trade-offs. Behavioural Ecology 13:280290. 
GUREJA, N. \& OWEN-SMITH, N. 2002. Comparative use of burnt grassland by rare antelope species in a lowveld game ranch, South Africa. South African Journal of Wildlife Research 32:31-38.

HIRST, S. M. 1975. Ungulate-habitat relationships in a South African woodland/savanna ecosystem. Wildlife Monographs 44: 3-60.

HUNGATE, R. E., PHIlliPS, G. D., MCGREGOR, A., HUNGATE, D. P. \& BUECHNER, H. K. 1959. Microbial fermentation in certain animals. Science 130:11921194.

HUNTLEY, B. J. \& WALKER, B. H. 1982. Ecology of tropical savannas. SpringerVerlag, Berlin. 669 pp.

ILLIUS, A. W. \& GORDON, I. J. 1992. Modelling the nutritional ecology of ungulate herbivores - evolution of body size and competitive interactions. Oecologia 89:428-434. MCDONALD, P., EDWARDS, R. A. \& GREENHALGH, J. F. D. 1966. Animal nutrition. Oliver and Boyd, Edinburgh. 407 pp.

MOE, S. R., WEGGE, P. \& KAPELA, E. B. 1990. The influence of man-made fires on large wild herbivores in Lake Burungi area in Northern Tanzania. African Journal of Ecology 28:35-43.

O'KANE, C. A. J., PAGE, B. \& MACDONALD, D. W. 2014a. Conducting animal censuses amongst abrupt topography; a GIS-based alternative to Distance. Austral Ecology 39:848-854.

O'KANE, C. A. J., PAGE, B. \& MACDONALD, D. W. 2014b. Differing influences of resource availability on the demographics and habitat selection of wildebeest compared to impala. Journal of Tropical Ecology 30:189-198. 
OWEN-SMITH, N. \& NOVELLIE, P. 1982. What should a clever ungulate eat? American Naturalist 119:151-178.

REDFERN, J. V., GRANT, R., BIGGS, H. \& GETZ, W. M. 2003. Surface-water constraints on herbivore foraging in the Kruger National Park, South Africa. Ecology 84:2092-2107.

SCHOLES, R. J. \& WALKER, B. H. 1982. An African savanna. Synthesis of the Nylsvlei study. Cambridge University Press, Cambridge. 318 pp.

SHACKLETON, C. M. 1992. Area and species selection by wild ungulates in coastal sour grasslands of Mkambati Game Reserve, Transkei, southern Africa. African Journal of Ecology 30:189-202.

STURM, H. J. 1993. Auswirkung von Feuer- und Beweidungsausschluß auf die Produktion der Krautschicht einer Strauchsavanne. Verhandlungen der Gesellschaft für Ökologie 22:323-328.

TALBOT, L. M. \& TALBOT, M. H. 1963. The wildebeest in Western Masailand, East Africa. Wildlife Monographs 12:1-88.

TOMOR, B. M. \& OWEN-SMITH, N. 2002. Comparative use of grass regrowth following burns by four ungulate species in the Nylsvley Nature Reserve, South Africa. African Journal of Ecology 40:201-204.

WILMSHURST, J. F., FRYXELL, J. M., FARM, B. P., SINCLAIR, A. R. E. \& HENSCHEL, C. P. 1999. Spatial distribution of Serengeti wildebeest in relation to resources. Canadian Journal of Zoology 77:1223-1232.

WILSEY, B. J. 1996. Variation in use of green flushes following burns among African ungulate species: the importance of body size. African Journal of Ecology 34:32-38. 
WRONSKI, T. 2003. Fire induced changes in the foraging behaviour of impala Aepyceros melampus in the Lake Mburo National Park, Uganda. African Journal of Ecology 41:56-60. 
Table 1. Ungulates' mean distances (metres) to surface water in Ithala Game Reserve, South Africa. Where the mean distance to surface water for a herbivore species in the dry season was significantly ( $\mathrm{P} \leq 0.05$; standard two-sample t-test or Welch's modified twosample t-test) different to that in the preceding wet season, this is shown as the percentage change going from wet to dry season (ns = not significant).

\begin{tabular}{lcccccc}
\hline Species & \multicolumn{3}{c}{ Year 3 } & & Year 4 \\
& Wet season & Dry season & $\%$ change & Wet season & Dry season & \% change \\
\hline Hartebeest & 233 & 222 & $\mathrm{~ns}$ & 370 & 258 & 70 \\
Impala & 169 & 213 & 126 & 221 & 128 & 58 \\
Warthog & 253 & 275 & 109 & 390 & 326 & 84 \\
White rhino & 227 & 147 & 65 & 216 & 196 & $\mathrm{~ns}$ \\
Wildebeest & 272 & 303 & 111 & 310 & 234 & 75 \\
Zebra & 274 & 189 & 69 & 304 & 237 & 78 \\
\hline
\end{tabular}


Fig. 1. Ungulates attracted to dry-season grass flushes in Ithala Game Reserve, South Africa. Ungulates that significantly ( $\mathrm{P} \leq 0.05$; Pearson's Chi-squared test with Yates' continuity correction) changed density on grasslands in response to dry-season grass flushes are shown, with filled columns showing densities before the flush, hatched columns during the flush. Light blue represents high-elevation, green mid-elevation and red low-elevation grasslands. 
Figure 1.

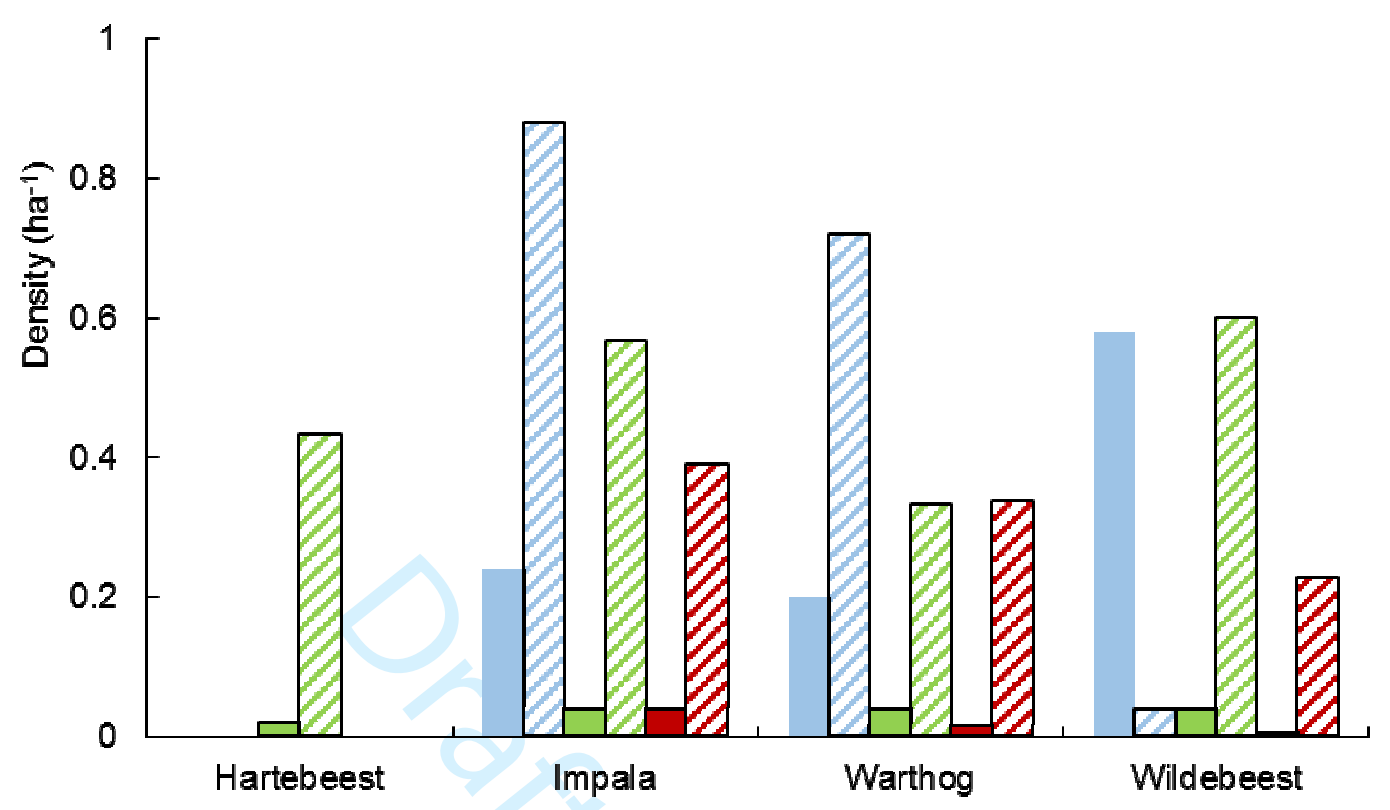

24

25

26

27

28

29

30

31

32

33

34

35

36

37

38

39

40

41

42

43

44

45

46

47

48

49

50

51

52

53

54

55

56

57

58

59

60

Draft For Review 